\title{
HSPB8 Gene
}

National Cancer Institute

\section{Source}

National Cancer Institute. HSPB8 Gene. NCI Thesaurus. Code C95433.

This gene plays a role in both protein folding and autophagy. 